Winder, F. G. \& Denneny, J. M. (1957). J. gen. Microbiol. 17, 573-585

\title{
The Metabolism of Inorganic Polyphosphate in Mycobacteria
}

\author{
By F. G. WINDER AND JOAN M. DENNENY \\ Laboratories of the Medical Research Council of Ireland, \\ Trinity College, Dublin
}

SUMMARY: Cell-free extracts of Mycobacterium smegmatis contain an inorganic polyphosphatase and a 'polyphosphate-AMP-phosphotransferase'. The latter enzyme, which synthesizes adenosine triphosphate from adenosine-5-monophosphate and inorganic polyphosphate, has a $\mathrm{pH}$ optimum of about 6.3 , and is stimulated by Mg. It does not appear to be attached to cell particles, and a slight purification may be effected by ammonium sulphate precipitation.

With a tracer technique it was shown that cellular inorganic polyphosphate is probably not the sole precursor either of lipid phosphorus or of nucleic acid phosphorus in $M$. smegmatis. The rapid accumulation of insoluble polyphosphate caused in $M$. smegmatis and $M$. phlei but not $M$. tuberculosis, by a number of organic substances, particularly alcohols, was studied. This accumulation takes place even after inoculation into a fresh nitrogenous medium, when polyphosphate normally decreases.

In a previous paper (Winder \& Denneny, 1956) we reported studies on the phosphorus-containing components of some mycobacteria. All the organisms studied contained inorganic polyphosphates. Although these substances occur in many lower plants, and in some animals, their metabolism has been the subject of comparatively little study. Polyphosphate metabolism in mycobacteria has been investigated by Ruska, Bringmann, Neckel \& Schuster (1952), Meissner \& Kropp (1953), Meissner \& Diller (1953) and Meissner \& Lemke (1955). The studies reported here were directed towards the elucidation of the following questions in the case of the mycobacteria. Are inorganic polyphosphates the direct source of other high-energy phosphorus compounds? Have they a close metabolic connexion with any other phosphorus fractions? How is their metabolism controlled in the cell?

\section{METHODS}

Organisms used. The organisms used and the conditions for growth have already been described (Winder \& Denneny, 1956).

Polyphosphate accumulation; short-term experiments. These experiments were similar to the previously described short-term growth experiments but with appropriately changed media; and the samples were treated and the phosphorus compounds extracted and determined as previously described (Winder \& Denneny, 1956).

Experiments with radioactive phosphorus. Four-day cultures of Mycobacterium smegmatis were washed with Proskauer \& Beck medium (P \& B) (American Trudeau Society, 1950) from which the nitrogen source (asparagine) 
was omitted, suspended by grinding in the same medium in a ball-mill, and brought to a standard turbidity (equivalent to $c .4 \mathrm{mg}$. dry wt./ml.). Forty $\mathrm{ml}$. of this suspension were pipetted into each of two $150 \mathrm{ml}$. flasks containing $20 \mathrm{ml}$. of nitrogen-free $\mathbf{P} \& \mathbf{B}$ medium, $2 \mathrm{ml} .65 \%(\mathrm{w} / \mathrm{v})$ tetrahydrofurfuryl alcohol (THFA) in water and $2 \mathrm{ml}$. of $0.5 \%(\mathrm{w} / \mathrm{v})$ Tween 80 . In one flask the phosphorus contained $0.5 \mathrm{mc}$ of ${ }^{32} \mathrm{P}$. The flasks were shaken in a water-bath at $37^{\circ}$ for $2 \mathrm{hr}$. while polyphosphate accumulation took place. The contents were then centrifuged, and the organisms washed twice by stirring in nitrogen-free $\mathrm{P} \& \mathrm{~B}$ medium and recentrifuging, suspended in $60 \mathrm{ml} . \mathrm{P} \& \mathrm{~B}$ medium and transferred to $150 \mathrm{ml}$. flasks containing $2 \mathrm{ml} .0 \cdot 5 \%(\mathrm{w} / \mathrm{v})$ Tween 80 . To the flasks containing the unlabelled organisms $0.5 \mathrm{mc}$ of ${ }^{32} \mathrm{P}$ were added. Samples were withdrawn at once and the flasks shaken at $37^{\circ}$ in the water bath. Further samples were withdrawn when required. The samples were washed and fractionated as described previously. Phosphorus determinations and ${ }^{32} \mathbf{P}$ counts were done on all the fractions, and on the medium. The specific activity of the inorganic polyphosphate was determined after precipitation with barium chloride at $\mathrm{pH} 4.5$. In the acid-soluble fraction, the orthophosphate and labile phosphates were precipitated with magnesia mixture after hydrolysis for $10 \mathrm{~min}$. with $\mathrm{N}-\mathrm{H}_{2} \mathrm{SO}_{4}$, and the specific activity of this precipitated phosphate was determined. From the figures obtained the concentrations and the specific activities of the lipid phosphorus, 'phosphoprotein', 'insoluble' polyphosphate, labile and stable acid-soluble phosphate, deoxypentosenucleic acid and pentosenucleic acid were calculated. Both nucleic acids contained, however, some uncharacterized phosphate.

Counting of radioactive samples. Samples (0.3 ml.) of the solutions (all in $5 \%$ trichloroacetic acid, TCA) were pipetted on to nickel planchettes and counted immediately under an end-window counter. Duplicate samples of each solution were counted, 10,000 counts being taken on each sample. Where duplicates did not agree to within $2 \%$, further samples were counted and the mean taken.

Preparation of cell-free extracts. Mycobacterium smegmatis from 4-day cultures was vigorously ground for 10-15 min. by hand in a chilled mortar with about the same weight of acid-washed alumina and enough cold $0 \cdot 1 \mathrm{M}$ phosphate buffer ( $\mathrm{pH} \mathrm{7 \cdot 2)}$ to make a slurry. (Use of insufficient buffer during the grinding may result in inactivation of enzyme.) The slurry was diluted with the buffer, chilled and centrifuged for $3 \times 10 \mathrm{~min}$. periods at about $3000 \mathrm{~g}$ to remove alumina, organisms and large cell-fragments. The extract was dialysed overnight at about $4^{\circ}$ against distilled water, and recentrifuged.

\section{Estimation of polyphosphate-AMP-phosphotransferase}

Method (i). This method relied on the presence in the extract of glycerolkinase, which caused the transfer of phosphate from adenosine triphosphate (ATP) or adenosine diphosphate (ADP) to glycerol, a reaction which went nearly to completion. One ml. of $0.5 \%(\mathrm{w} / \mathrm{v}) \mathrm{MgSO}_{4} \cdot 7 \mathrm{H}_{2} \mathrm{O}, 1 \mathrm{ml}$. of $2 \%(\mathrm{w} / \mathrm{v})$ glycerol in water, and $1 \mathrm{ml}$. of $0.5 \mathrm{M}$-succinate buffer ( $\mathrm{pH} \mathrm{6.3}$ ), were pipetted into a test tube and $1 \mathrm{ml}$. of a $0.2 \%(\mathrm{w} / \mathrm{v})$ solution of adenosine-5-mono- 
phosphate (AMP), and $1 \mathrm{ml}$. of sodium pholyphosphate solution were added. Three ml. of cell-extract was added, the solutions mixed, and $2 \mathrm{ml}$. samples pipetted into $2 \mathrm{ml}$. volumes of $10 \%$ trichloroacetic acid (TCA). Control tubes lacking polyphosphate and nucleotide were also set up. The tubes werestoppered, incubated at $37^{\circ}$ for $3-5 \mathrm{hr}$. and further samples were taken. The sample tubes were capped, heated for $10 \mathrm{~min}$. at $90^{\circ}$ (to extract the polyphosphate from the precipitated protein), centrifuged, and the supernatant fluid used for the determination of the sum of inorganic and acid-labile phosphate. The decrease in this figure during incubation was a measure of the amount of stable phosphate ester (glycerophosphoric acid) formed and hence, for the reason mentioned above, a measure of the formation of ATP and ADP.

Method (ii). This relied on the direct determination of the nucleotides. The incubation mixture was the same as in Method (i), but without glycerol. Control tubes were incubated without AMP and polyphosphate. After $3 \mathrm{hr}$. $6 \mathrm{ml} .10 \%(\mathrm{w} / \mathrm{v})$ TCA were added to each tube. The tubes were then left in the cold for $1 \mathrm{hr}$., extracted twice with $20 \mathrm{ml}$. lots of ether (to decrease the TCA content) and neutralized. The solutions were put on Dowex 1 columns and the nucleotides eluted according to the method of Cohn \& Carter (1950). The eluates were collected in $10 \mathrm{ml}$. lots and their absorption read at $260 \mathrm{~m} \mu$.

Chemicals. The inorganic polyphosphate used was sodium metaphosphate (Hopkin \& Williams). A $2 \%(\mathrm{w} / \mathrm{v})$ suspension in $1 \%(\mathrm{w} / \mathrm{v}) \mathrm{K}_{2} \mathrm{SO}_{4}$ was adjusted to $\mathrm{pH} 7 \cdot 4$, kept overnight, its $\mathrm{pH}$ value readjusted to the required value, the suspension centrifuged, and the supernatant fluid diluted $1: 1$ with water.

Adenosine-5-monophosphoric acid, adenosine-3-monophosphoric acid (A-3. MP) and other nucleoside derivatives were obtained from Schwarz Laboratories, New York 17, except ADP and ATP which were obtained as the barium salts from L. Light and Co. Colnbrook, Bucks.

\section{RESULTS}

Conditions for abnormal polyphosphate accumulation

When material from a 4-day culture of Mycobacterium smegmatis was incubated in nitrogen-free $\mathbf{P} \& \mathbf{B}$ medium, little further accumulation of insoluble polyphosphate took place. When, however, $2 \%$ tetrahydrofurfuryl alcohol (THFA) was included in the medium a rapid accumulation of insoluble polyphosphate was observed (Table 1 ) as previously reported (Winder \& Denneny, 1954). There was no substantial change in any of the other fractions, except on occasion an increase in the acid-soluble labile phosphate. This was not found in the experiment illustrated in Table 1 . It was found that when $M$. smegmatis was grown in the presence of THFA the organisms contained a greatly increased concentration of polyphosphate, both soluble and insoluble (Table 2). There was a slight increase in most other phosphorus fractions and a decrease in the deoxyribonucleic acid (DNA) content.

In order to explain the accumulation of polyphosphate, it was first postulated that THFA inhibited its utilization. On incubating Mycobacterium smegmatis 


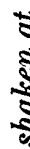

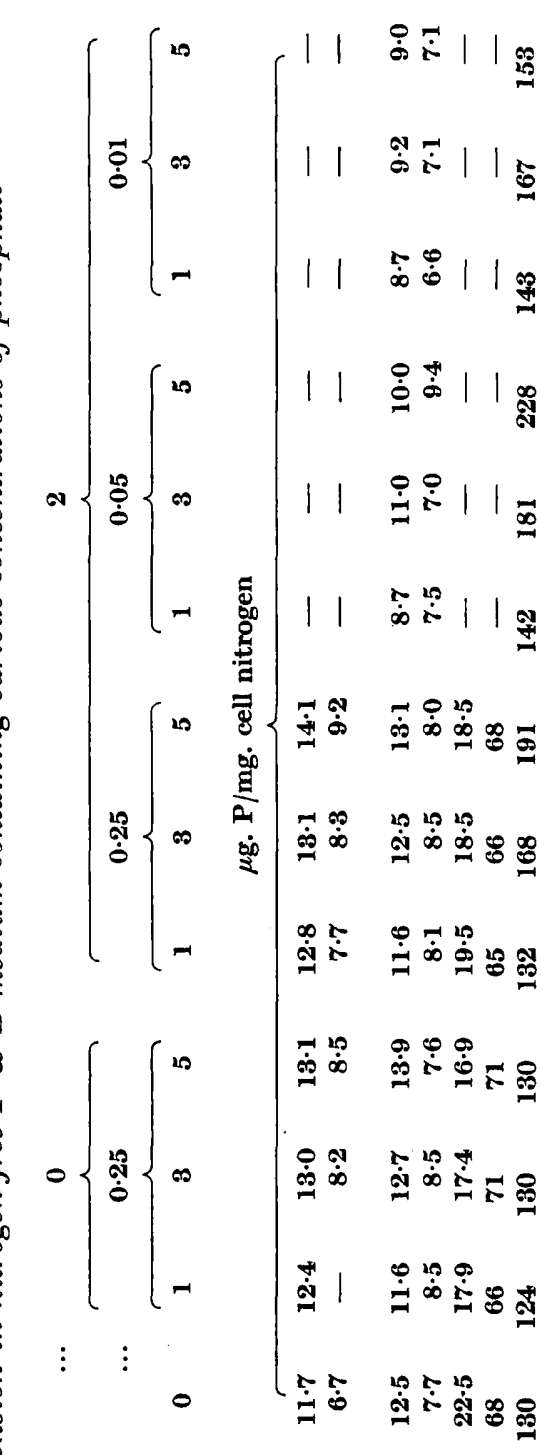

害实
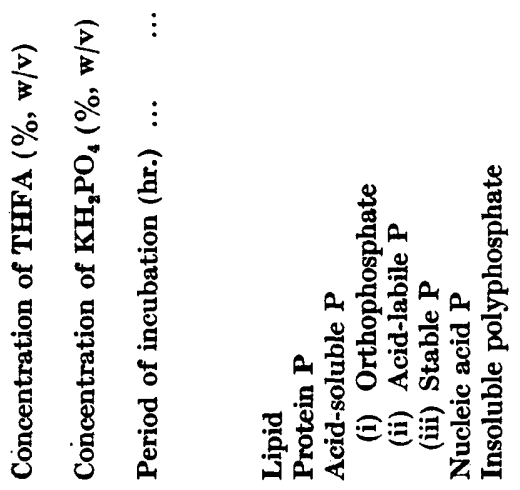


\section{Polyphosphate metabolism in mycobacteria}

in nitrogen-free $\mathbf{P} \& \mathbf{B}$ medium containing ${ }^{32} \mathbf{P}$ it was found, however, that THFA strongly stimulated the incorporation of ${ }^{32} \mathbf{P}$ into polyphosphate. Another possibility considered was that THFA damaged the organisms in such a way as to permit the free entry of external phosphate, and that the organisms responded by forming polyphosphate to decrease the amount of the orthophosphate. This theory was not supported by studies on the effect of changing the concentration of phosphate in the medium (Table 1). Accumulation was still observed with $0.01 \%(w / v) ~ \mathbf{K H}_{2} \mathrm{PO}_{4}$, although the organisms

Table 2. Effect of tetrahydrofurfuryl alcohol $(T H F A)$ in growth medium $(P \& B)$ on composition of Mycobacterium smegmatis harvested after 6 days of incubation

\begin{tabular}{|c|c|c|c|c|c|c|}
\hline $\begin{array}{l}\text { THFA concentration } \\
(\%, \mathbf{w} / \mathbf{v})\end{array}$ & 1 & $0 \cdot 7$ & $0 \cdot 3$ & $\mathbf{0} \cdot 13$ & 0.07 & $\mathbf{0}$ \\
\hline & & & $\mathbf{P} / \mathrm{mg}$ & 1 nitro & & \\
\hline Lipid-P & $16 \cdot 3$ & $15 \cdot 2$ & $16 \cdot 4$ & $13 \cdot 7$ & $14 \cdot 1$ & $15 \cdot 0$ \\
\hline Acid-soluble $\mathbf{P}$ & & & & & & \\
\hline (i) Orthophosphate & $16 \cdot 2$ & $12 \cdot 9$ & $11 \cdot 5$ & $12 \cdot 0$ & $10 \cdot 6$ & $18 \cdot 0$ \\
\hline (ii) Acid-labile $\mathbf{P}$ & $23 \cdot 1$ & $12 \cdot 1$ & $10 \cdot 1$ & $7 \cdot 8$ & $\mathbf{5 \cdot 2}$ & $5 \cdot 7$ \\
\hline (iii) Stable P & $25 \cdot 6$ & $\mathbf{2 3} \cdot \mathbf{3}$ & $21 \cdot 8$ & $20 \cdot 6$ & $18 \cdot 5$ & $10 \cdot 5$ \\
\hline PNA-P & $\mathbf{5 9} \cdot \mathbf{1}$ & $61 \cdot 3$ & $61 \cdot 5$ & $58 \cdot 4$ & $57 \cdot 2$ & $53 \cdot 8$ \\
\hline DNA-P & $42 \cdot 6$ & $42 \cdot 6$ & $40 \cdot 6$ & $38 \cdot 8$ & $\mathbf{5 3 \cdot 5}$ & $56 \cdot 3$ \\
\hline Insoluble polyphosphate & 297 & 242 & 189 & $14 \theta$ & 130 & 125 \\
\hline
\end{tabular}

contained a higher orthophosphate concentration. Further, with low external phosphate and THFA, the concentration of cellular orthophosphate dropped while polyphosphate accumulation took place (Table 1). The results, therefore, force the conclusion that THFA stimulated polyphosphate synthesis either by direct stimulation of the enzymes involved, by inactivation of some controlling mechanism, or by causing some structural disorganization so that in its presence increased amounts of phosphate reach the polyphosphate-forming regions. There appears to be no serious damage to the organisms, however, since Table 2 shows accumulation of polyphosphate in the presence of THFA in organisms which were still growing vigorously. It was found too that the number of viable organisms was almost unaffected by a $5 \mathrm{hr}$. incubation with $5 \%(w / v)$ THFA.

In the absence of THFA the addition of nitrogen to the incubation medium resulted in a decreased concentration of polyphosphate in Mycobacterium smegmatis, but when THFA was present the addition of nitrogen did not lead to a decreased formation of polyphosphate, although the utilization of phosphate for other purposes was increased (Table 3). The significance of this will be discussed later. Table 3 also shows that in the presence of nitrogen THFA had further effects and in particular caused an inhibition of DNA synthesis.

THFA caused rapid polyphosphate accumulation only over a narrow range of concentrations; at $0.5 \%(w / v)$ the effect was slight and at $5 \%(w / v)$ it was past its optimum, which was at about $2 \%(w / v)$. Over longer periods, 
however, concentrations of THFA even below $0.1 \%(w / v)$ caused some polyphosphate accumulation (Table 2).

A number of substances other than THFA were tested for their effect on polyphosphate accumulation (Table 4). The list is too brief to show definitely what chemical or physical properties are associated with stimulation of polyphosphate accumulation; the active substances are all lipid-soluble.

Table 3. Effect of tetrahydrofurfuryl alcohol (THFA) on changes in phosphorus fractions of Mycobacterium smegmatis shaken at $37^{\circ}$ as a heavy suspension in $P \& B$ medium with and without a nitrogen source

Concentration of asparagine

$\begin{array}{ll}\begin{array}{l}(\%, w / v) \\ \text { Concentration of THFA } \\ (\%, w / v)\end{array} & \cdots \\ & \cdots\end{array}$
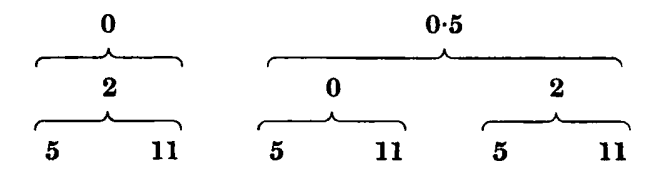

Period of incubation (hr.) $\quad \ldots \quad 0$

$\mu \mathrm{g} . \mathrm{P} / 10 \mathrm{ml}$. suspension

Lipid P
Protein $\mathbf{P}$
Acid-soluble P (excluding
$\quad$ orthophosphate)
PNA-P
DNA-P
Insoluble polyphosphate

Total nitrogen

\begin{tabular}{|c|c|c|c|c|c|c|}
\hline $30 \cdot 9$ & $29 \cdot 8$ & $\mathbf{3 0} \cdot \mathbf{3}$ & $30 \cdot 0$ & $39 \cdot 5$ & $29 \cdot 3$ & $34 \cdot 7$ \\
\hline 18.8 & $17 \cdot 2$ & $17 \cdot 9$ & $17 \cdot 5$ & 23.1 & $17 \cdot 0$ & $25 \cdot 2$ \\
\hline $46 \cdot 6$ & $54 \cdot 1$ & $65 \cdot \theta$ & $47 \cdot 8$ & $65 \cdot 8$ & $48 \cdot 6$ & $68 \cdot 2$ \\
\hline $99 \cdot 9$ & $94 \cdot 2$ & $87 \cdot 3$ & 105 & 140 & $99 \cdot 6$ & 141 \\
\hline $47 \cdot 1$ & $49 \cdot 2$ & $50 \cdot 0$ & 53.0 & $69 \cdot 8$ & $49 \cdot 4$ & $54 \cdot 2$ \\
\hline 889 & 408 & 597 & 278 & 232 & 422 & 592 \\
\hline
\end{tabular}

mg. $\mathrm{N} / 10 \mathrm{ml}$. suspension

$\begin{array}{lllllll}2.60 & 2.66 & 2.63 & 2.74 & 3.75 & 2.67 & 3.51\end{array}$

Table 4. Comparison of a number of chemicals with tetrahydrofurfuryl alcohol $(T H F A)$ as stimulators of. polyphosphate accumulation in Mycobacterium smegmatis shaken with them for $3 \mathrm{hr}$. at $37^{\circ}$ in nitrogen-free $\boldsymbol{P} \& B$ medium

\begin{tabular}{|c|c|c|}
\hline Chemical & $\begin{array}{c}\text { Concentration } \\
(\%, w / v)\end{array}$ & $\begin{array}{l}\text { Increase in poly- } \\
\text { phosphate as a } \% \\
\text { of that caused by } \\
2.5 \%(w / v) \text { THFA }\end{array}$ \\
\hline Ethanol & $\begin{array}{l}2 \cdot 0 \\
1 \cdot 6\end{array}$ & $\begin{array}{l}25 \\
32\end{array}$ \\
\hline Tetrahydrofuran & $\begin{array}{l}2 \cdot 0 \\
1 \cdot 6\end{array}$ & $\begin{array}{l}\mathbf{3 2} \\
89\end{array}$ \\
\hline Butanol & $1 \cdot 0$ & 91 \\
\hline Acetaldehyde & $\begin{array}{l}\mathbf{2 \cdot 0} \\
\mathbf{0} \cdot \mathbf{3}\end{array}$ & $\begin{array}{l}\text { Decrease } \\
63\end{array}$ \\
\hline Propylene glycol & $\mathbf{2 \cdot 0}$ & $\mathbf{0}$ \\
\hline Butyrate & $1 \cdot 0$ & Decrease \\
\hline Caproate & $\begin{array}{l}0.5 \\
0.1\end{array}$ & $\begin{array}{l}\text { Decrease } \\
\text { Decrease }\end{array}$ \\
\hline Salicylate & $\mathbf{0} \cdot \mathbf{6}$ & Decrease \\
\hline Hydroquinone & $0 \cdot 2$ & Decrease \\
\hline Ferric chloride & $1 \cdot 0$ & Decrease \\
\hline Chloromycetin & $0 \cdot 0005$ & $\mathbf{0}$ \\
\hline Anilinoaposafranine & $0 \cdot 004$ & Decrease \\
\hline
\end{tabular}




\section{Polyphosphate metabolism in mycobacteria}

At concentrations of up to $3 \%$ (w/v), THFA had no immediate effect on the respiration of Mycobacterium smegmatis in nitrogen-free $\mathbf{P} \& \mathbf{B}$ medium, but after $5 \mathrm{hr}$. of incubation with $\mathbf{0 \cdot 5 - 2} \%$ (w/v) THFA, respiration decreased by c. $10 \%$. When THFA was supplied as the sole respiratory substrate it was apparently metabolized, as the respiration rate was raised over the endogenous level and remained above that level for $5 \mathrm{hr}$.

The omission of either $\mathbf{K}$ or $\mathbf{M g}$ from the incubation medium decreased the accumulation of polyphosphate in the presence of THFA. No attempt was made to eliminate all traces of these metals, so it cannot be stated whether there is an absolute requirement for either of these elements for polyphosphate formation.

2,4-Dinitrophenol (2 mM) caused complete inhibition of polyphosphate accumulation, with only $30 \%$ inhibition of respiration. At a concentration of $1 \mathrm{~mm}$ it caused $70 \%$ inhibition of accumulation with little or no effect on respiration. Sodium azide $(9 \mathrm{~mm})$ caused $45 \%$ inhibition of accumulation with $10 \%$ inhibition of respiration, and at $3 \mathrm{~mm}$ it caused $30 \%$ inhibition with no effect on respiration.

This stimulation of polyphosphate formation by THFA was not confined to Mycobacterium smegmatis; it was also shown by $\boldsymbol{M}$. phlei, though not as strongly. $M$. tuberculosis $\mathrm{H} 37 \mathrm{Ra}$ and $\mathrm{R} 1 \mathrm{Ra}$ did not show this effect; virulent strains of $M$. tuberculosis were not investigated.

\section{Isotope studies on metabolic function of polyphosphate}

The labelling of the different phosphorus fractions was followed by adding labelled orthophosphate to growing cultures of Mycobacterium smegmatis. Insoluble polyphosphate was labelled less rapidly than cellular inorganic phosphate, and more rapidly than the various fractions insoluble in cold TCA. To determine whether insoluble polyphosphate was the exclusive precursor of any other phosphorus fraction, the experiment described under Methods was carried out. This consisted of two simultaneous and identical growth experiments, one starting with labelled external orthophosphate, and the other starting with most of the ${ }^{32} \mathrm{P}$ in the cellular polyphosphate.

If the system of an exclusive precursor $A$ transferring phosphorus to a product $\mathrm{B}$, which may in turn transfer it to other products (including back to $A$ ), is considered, the following relationship holds for any short period:

$$
a=\frac{\Delta^{32} \mathbf{P}_{\mathrm{B}}-\Delta \mathbf{P}_{\mathrm{B}} \times \mathrm{act}_{\mathrm{B}}}{\mathrm{act}_{\mathrm{A}}-\mathrm{act}_{\mathrm{B}}}
$$

(where $a$ is the phosphorus gained by $\mathbf{B}$ from $\mathbf{A}$ during the period, $\Delta^{32} \mathbf{P}_{\mathbf{B}}$ is the net increase in ${ }^{32} \mathrm{P}$ in $\mathrm{B}$ during the period, $\Delta \mathbf{P}_{\mathrm{B}}$ is the net increase in total phosphorus in $B$ during the period, act t $_{\mathbf{A}}$ and act $_{B}$ are the mean specific activities of $A$ and $B$ during the period). Hence, to determine whether any fraction, $A$, is the exclusive precursor of any other fraction, $B$, the value of $a$ can be calculated for any period in the experiment, both for the cells in the labelled phosphate medium and those with labelled polyphosphate. For each 
period the value of $a$ obtained in the two cases should be the same, if the assumed precursor-product relationship is correct.

The results of the experiments (some of which are given in Table 5) were studied in this way for possible precursor-product relationships. Polyphosphate was not the exclusive precursor of either of the nucleic acid fractions

Table 5. The distribution of ${ }^{32} \mathrm{P}$ from labelled external phosphate and cellular polyphosphate during the growth of Mycobacterium smegmatis in $\boldsymbol{P} \& \boldsymbol{B}$ medium

\begin{tabular}{|c|c|c|c|c|c|}
\hline \multirow{2}{*}{$\begin{array}{c}\text { Period of } \\
\text { incubation } \\
(\mathrm{hr} .)\end{array}$} & \multirow{2}{*}{$\begin{array}{c}\text { P content } \\
\text { of fraction } \\
(\mu \mathrm{g} . \mathrm{P} / 10 \mathrm{ml} \text {. } \\
\text { suspension) }\end{array}$} & \multicolumn{2}{|c|}{$\begin{array}{c}\text { Specific activity } \\
\text { (counts/min./ } \mu \mathrm{g} . \mathrm{P})\end{array}$} & \multirow{2}{*}{$\begin{array}{c}\text { True PNA } \\
(\mu \text { g. P/10 ml. })\end{array}$} & \multirow[b]{2}{*}{$\begin{array}{c}\text { True DNA } \\
(\mu \mathrm{g} . \mathrm{P} / 10 \mathrm{ml} .)\end{array}$} \\
\hline & & Flask A & Flask B & & \\
\hline \multicolumn{6}{|c|}{ External orthophosphate } \\
\hline 0.0 & & $0 \cdot 0$ & 970 & & \\
\hline \multicolumn{6}{|c|}{ Insoluble polyphosphate } \\
\hline 0.0 & 760 & $72 \cdot 5$ & 0.0 & & \\
\hline 1.4 & 774 & $88 \cdot 5$ & 24.5 & & \\
\hline $\mathbf{3} \cdot \mathbf{0}$ & 718 & 88.8 & $48 \cdot 5$ & & \\
\hline $6 \cdot 0$ & 584 & $67 \cdot 5$ & $91 \cdot 0$ & & \\
\hline $10 \cdot 2$ & 452 & $\mathbf{5 5 \cdot 0}$ & $171 \cdot 6$ & & \\
\hline \multicolumn{6}{|c|}{ Phospholipid } \\
\hline 0.0 & $21 \cdot 0$ & $11 \cdot 4$ & $0 \cdot 0$ & & \\
\hline $1 \cdot 4$ & 24.7 & $25 \cdot 3$ & $12 \cdot 0$ & & \\
\hline 3.0 & $29 \cdot 6$ & $38 \cdot 3$ & $51 \cdot 8$ & & \\
\hline 6.0 & $33 \cdot 1$ & 51.7 & $123 \cdot 0$ & & \\
\hline $10 \cdot 2$ & $35 \cdot 2$ & $41 \cdot 7$ & $218 \cdot 0$ & & \\
\hline \multicolumn{6}{|c|}{ PNA + unknown $P$} \\
\hline 0.0 & 365 & 18.9 & $0 \cdot 0$ & 262 & \\
\hline $1 \cdot 4$ & 370 & $28 \cdot 1$ & $9 \cdot 2$ & 266 & \\
\hline $3 \cdot 0$ & 371 & 34.3 & $34 \cdot 2$ & 270 & \\
\hline 6.0 & 386 & 68.7 & $85 \cdot 5$ & 273 & \\
\hline $10 \cdot 2$ & 430 & 58.7 & 161.5 & 326 & \\
\hline \multicolumn{6}{|c|}{ DNA + unknown P } \\
\hline 0.0 & 144 & $5 \cdot 2$ & 0.0 & & 130 \\
\hline $1 \cdot 4$ & 148 & $22 \cdot 9$ & $9 \cdot \boldsymbol{\theta}$ & & 133 \\
\hline $\mathbf{8 \cdot 0}$ & 153 & 33.0 & $28 \cdot 3$ & & 189 \\
\hline 6.0 & 173 & - & $72 \cdot 4$ & & - \\
\hline $10 \cdot 2$ & 210 & $65 \cdot 0$ & $182 \cdot 8$ & & 182 \\
\hline \multicolumn{6}{|c|}{ Stable acid-soluble $\mathbf{P}$} \\
\hline 0.0 & $120 \cdot 3$ & 194 & 168 & & \\
\hline $1 \cdot 4$ & $100 \cdot 7$ & $97 \cdot 3$ & 205 & & \\
\hline $\mathbf{3 \cdot 0}$ & 98.5 & $81 \cdot 6$ & 368 & & \\
\hline 6.0 & - & - & - & & \\
\hline $10 \cdot 2$ & $78 \cdot 0$ & 66.5 & 461 & & \\
\hline
\end{tabular}

(though the presence of some uncharacterized phosphate left some doubt), nor of phospholipid. Likewise, the origin of polyphosphate could not be identified with any of the other fractions studied. The results suggest that the precursor of polyphosphate is closely related to the external phosphate, and hence is probably one of the acid-soluble fractions. Further experiments 
along the same lines, with a full analysis of the acid-soluble components, are required to obtain a full understanding of the metabolic relationships of polyphosphate.

\section{Metabolism of polyphosphate by cell-free extracts of \\ Mycobacterium smegmatis}

Cell-free extracts of Mycobacterium smegmatis contain an inorganic polyphosphatase stimulated by magnesium ions, with an optimum activity above pH 7. This enzyme was not investigated further. It was also found that the extracts contained an enzyme which appeared to be capable of using inorganic polyphosphate for the synthesis of ATP from ADP (Winder \& Denneny, 1955). The presence of this enzyme was first established by the indirect method of showing an increased synthesis of glycerophosphoric acid from glycerol and ATP in the presence of inorganic polyphosphate (see Methods). Since, under the conditions of these experiments neither polyphosphate alone, nor polyphosphate + AMP, was able to cause an appreciable phosphorylation of glycerol it appeared that polyphosphate served to regenerate ATP from ADP. However, analysis on Dowex 1 ion exchange resin (see Methods) of the nucleotides formed on incubation of the extracts with polyphosphate and ADP showed that no ATP was formed. Synthesis of ADP from AMP and polyphosphate was, however, found to occur when the system was buffered at $\mathrm{pH} 6 \cdot 3$. Further work explained the earlier negative results obtained with $\mathbf{A M P}$. The enzyme involved had a $\mathrm{pH}$ optimum between $6 \cdot 0$ and 6.5 , and showed little activity at $\mathrm{pH} 7$; the earlier work had been done at $\mathrm{pH} \mathbf{7 \cdot 4}$, but the system was weakly buffered so that when ATP or ADP was incubated the $\mathrm{pH}$ value was brought to 6.5 by phosphatase action. When AMP was added instead, the decrease in $\mathrm{pH}$ value was small and consequently the transphosphorylating enzyme was inactive. When the system was buffered at $\mathrm{pH} 6 \cdot 3$, the extract was able to phosphorylate glycerol, using AMP and polyphosphate. Hence, the enzyme is best described as a polyphosphateAMP-phosphotransferase. Centrifugation at $25,000 \mathrm{~g}$ for $1 \mathrm{hr}$. left all the activity in the supernatant fluid. Hence, the enzyme appeared to be in solution in the extracts, though attachment to small particles was not excluded. Only preliminary work has been done on the purification of this enzyme. It was inactivated by precipitation with acetone. Fractionation with ammonium sulphate was more successful, most of the activity being precipitated between 1/4 and 1/2 saturation. A partial purification was carried out as follows: the undialysed extract was saturated with ammonium sulphate, left for $1 \mathrm{hr}$. at $4^{\circ}$ and centrifuged. The precipitate was dissolved in $0.1 \mathrm{M}$-phosphate buffer $(\mathrm{pH} \mathrm{7.2)} \mathrm{ammonium} \mathrm{sulphate} \mathrm{added} \mathrm{to} \mathrm{half} \mathrm{saturation,} \mathrm{the} \mathrm{suspension} \mathrm{left} \mathrm{for}$ $1 \mathrm{hr}$. at $4^{\circ}$ and centrifuged. The precipitate was dissolved in phosphate buffer, and the solution again centrifuged. The clear solution contained $50 \%$ of the initial phosphotransferase, with considerably decreased polyphosphatase and other phosphatase activities, but it still contained the glycerolkinase.

A complete characterization of the enzyme must await further purification, on account of the polyphosphatases still present in the extracts. As already 
mentioned the optimum $\mathrm{pH}$ lies in the range of 6.0-6.5. The enzyme is stimulated by $\mathrm{Mg}$ at a concentration of $0.0003 \mathrm{M}$. It was active in the absence of added $\mathbf{M g}$, but this may have been due to traces of $\mathbf{M g}$ in the extract.

The polyphosphate used contained a range of products from orthophosphate to high molecular weight polymers. When it was freed from the dialysable material it still served as a substrate for the polyphosphate-AMP-phosphotransferase. Short-chain polymers were not tested, except pyrophosphate, which did not serve as a substrate.

It appears that there are a number of enzymes for polyphosphate utilization present in Mycobacterium smegmatis. Some nucleosides (guanosine and uridine) were phosphorylated to a slight extent by the extracts in the presence of polyphosphate, while A-3-MP was also phosphorylated. These effects, however, were slight and require further investigation. The extracts appeared to lack a myokinase type of enzyme, as formation of ADP from AMP does not result in any increase in ATP. An enzyme was present for the direct phosphorylation of glycerol from ADP. The presence of a myokinase has been shown (Oliver \& Peel, 1956) in $M$. phiei extracts, however.

\section{DISCUSSION}

The available evidence suggests that inorganic polyphosphates are synthesized in the cell from nucleoside polyphosphates (Yoshida \& Yamataka, 1953; Kornberg, Kornberg \& Simms, 1956; Lieberman \& Eto, 1956). They are utilized either by hydrolysis to orthophosphate (polyphosphatases are present in a wide range of organisms) or by reversal of the synthetic reactions (Hoffmann-Ostenhof et al. 1954; Winder \& Denneny, 1955). The results in this paper show that mycobacteria contain enzymes for the utilization of inorganic polyphosphates by both of these pathways. The value of inorganic polyphosphates in mycobacteria, and indeed in other organisms, is not clear, however. The polyphosphate in a 'resting' mycobacterial cell could provide enough phosphorus for another cell generation, but as a source of energy it is comparatively insignificant. The suggestion has been made that these polyphosphates have some special function connected with nucleic acid or protein synthesis, but no reliable evidence for this has been forthcoming. Our results with labelled phosphorus suggest that inorganic polyphosphates are not the sole precursors either of nucleic acid or lipid phosphorus, and are in keeping with the idea that they are utilized via the pool of acid-soluble phosphorus compounds. However, the results are not conclusive, nor was the work brought far enough to indicate the relative importance of metabolism through nucleotides and through orthophosphate, or whether other pathways exist.

As in other organisms, part of the inorganic polyphosphate in mycobacteria is 'soluble' and part 'insoluble' in cold $5 \%$ trichloroacetic acid depending on the degree of polymerization (Katchman \& van Wazar, 1954), and the two fractions are metabolized differently. Of course, the dividing line between the two 'solubility' fractions may not correspond precisely with the metabolic dividing line, and both fractions may be metabolically inhomogeneous. 
From studies on the metabolism of inorganic polyphosphate in yeast (Juni, Kamen, Spiegelman \& Wiame, 1947; Juni, Kamen, Reiner \& Spiegelman, 1948; Wiame, 1949; Hoffmann-Ostenhof, Klima, Kenedy \& Keck, 1955), in Corynebacterium diphtheriae (Davis \& Mudd, 1955; Sall, Mudd \& Davis, 1956), in Aerobacter aerogenes (Duguid, Smith \& Wilkinson, 1954; Smith, Wilkinson \& Duguid, 1954), in Acetabularia (Stich, 1953), and in mycobacteria (Winder \& Denneny, 1954, 1956) it is evident that polyphosphate (particularly 'insoluble' polyphosphate) is accumulated when the demand for high-energy phosphate drops, due to slowing of growth caused by unfavourable circumstances. When conditions again permit rapid growth polyphosphate utilization exceeds formation and its level in the cell drops. This suggests that supply and demand for phosphorus and energy control the level of inorganic polyphosphate.

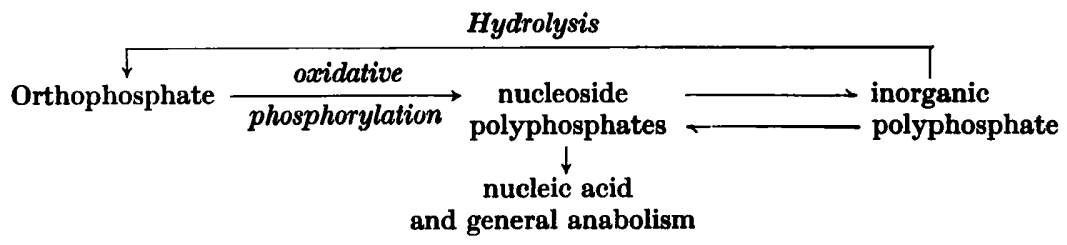

Some of the work referred to above shows that this simple picture is incomplete, however, and the results in this paper raise further difficulties. Even with an unlimited supply of oxidizable substrate and phosphorus, polyphosphate accumulation does not continue indefinitely, and hence a controlling mechanism must operate when polyphosphate reaches a certain level in the cell. In Mycobacterium smegmatis and $M$. phlei this control is removed when substances sueh as THFA are added. Further, the ability of THFA to stimulate polyphosphate formation without reducing nitrogen assimilation suggests that, if polyphosphate is formed from the same pool of high energy phosphates as are used for assimilation, the compounds in this pool can be formed at a faster rate than they are required for assimilation. Why then does the start of assimilation normally (THFA absent) result in a drop in polyphosphate? This drop would appear not to be due solely to increased demand for high-energy phosphate, but to some other controlling mechanism coming into operation, and one which is also removed by THFA. This controlling factor may be the level of nucleotides available for phosphorus transfer, and THFA by reducing DNA synthesis may increase the level of nucleotides. On the other hand, THFA may possibly stimulate oxidative phosphorylation. These controls may, of course, be through cellular organization, and THFA may disturb this, which calls to mind the effect of certain organic solvents in stimulating mammalian histidine decarboxylase (Waton, 1956).

We wish to thank Dr Vincent C. Barry, the Director of these laboratories, for encouragement and stimulating discussion, and Messrs Arthur Guinness, Son and Co. (Dublin) Ltd., for financial assistance. 


\section{REFERENCES}

American Trudeau Society (1950). Report on the Laboratory Sub-commmittee of the Committee on Medical Research and Therapy. Amer. Rev. Tuberc. 61, 274.

Cohn, W. E. \& Carter, C. E. (1950). The separation of adenosine polyphosphates by ion exchange and paper chromotography. J. Amer. chem. Soc. 72, 4273.

Davis, J. C. \& MUDD, S. (1955). The cytology of a strain of Corynebacterium diphtheriae. J. Bact. 69, 372.

Duguid, J. P., Smith, I. W. \& Wilkinson, J. F. (1954). Volutin production in Bacterium aerogenes due to development of an acid reaction. J. Path. Bact. 67, 289.

Hoffmann-Ostenhof, O., Kenedy, J., Keck, K., Gabriel, O. \& Schönfellinger, H. W. (1954). Ein neues Phosphat-übertragendes Ferment aus Hefe. Biochim. biophys. Acta, 14, 285.

Hoffmann-Ostenhof, O., Klima, A., Kenedy, J. \& Keck, K. (1955). Zur Kenntnis des Phosphatstoffwechsels der Hefe. I. Quantitative Untersuchungen über das Verhalten verschiedener Phosphatfraktionen unter bestimmten Stoffwechselbedingungen. Mh. Chem. 86, 604 .

Juni, E., Kamen, M. D., Spiegelman, S. \& Wiame, J. M. (1947). Physiological heterogeneity of metaphosphate in yeast. Nature, Lond. 160, 717.

Juni, E., Kamen, M. D., Reiner, J. M. \& Spiegelman, S. (1948). Turnover and distribution of phosphate compounds in yeast metabolism. Arch. Biochem. 18, 387.

Katchman, B. J. \& van Wazer, J. R. (1954). The 'soluble' and 'insoluble' polyphosphates of yeast. Biochim. biophys. Acta, 14, 445.

Kornberg, A., Kornberg, S. R. \& Simms, E. S. (1956). Metaphosphate synthesis by an enzyme from Escherichia coli. Biochim. biophys. Acta, 20, 215.

Lieberman, I. \& Eto, W. H. (1956). Inorganic triphosphate synthesis by muscle adenylate kinase. J. biol. Chem. 219, 307.

Meissner, J. \& Diller, W. (1953). Utber die Aufnahme von Ortho- und Metaphosphate durch das Mycobacterium tuberculosis. Z. Hyg. InfektKr. 137, 518.

Meissner, J. \& Kropp, F. (1953). Über die Phosphatresorption beim Mycobacterium tuberculosis. Z. Hyg. InfehtKr. 137, 429.

Meissner, J. \& Lemke J. (1955). Utber die Aufnahme ${ }^{32}$ P-markierter kondensierter Phosphate bei BCG- und H 37-Stämmen von Mycobacterium tuberculosis. Z. Hyg. InfektKr. 141, 249.

Oliver, I. T. \& PEEL, J. L. (1956). Myokinase activity in microorganisms. Biochim. biophys. Acta, 20, 390.

Ruska, H., Bringmann, G., Neckel, I. \& Schuster, G. (1952). Über die Entwicklung sowie den morphologischen und zytochemischen Aufbau v. Mycobacterium avium (Chester). Z. wiss. Mikr. 60, 425.

Sall, T., Mudd, S. \& Davis, J. C. (1956). Factors conditioning the accumulation and disappearance of metaphosphate in cells of Corynebacterium diphtheriae. Arch. Biochem. Biophys. 60, 130.

Smith, I. W., Wilkinson, J. F. \& Duguid, J. P. (1954). Volutin production in Aerobacter aerogenes due to nutrient imbalance. J. Bact. 68, 450.

Sтісн, H. (1953). Der Nachweis und das Verhalten von Metaphosphaten in normalen, verdunkelten und Trypaflavin-behandelten Acetabularien. Z. Naturf. 8b, 36.

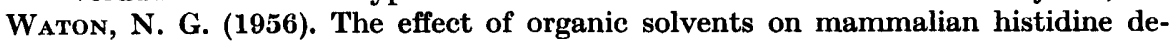
carboxylase. Biochem. J. 64, 318.

Wiame, J. M. (1949). The occurrence and physiological behaviour of two metaphosphate fractions in yeast. J. biol. Chem. 178, 919.

WinDER, F. \& DENNENY, J. M. (1954). Metaphosphate in mycobacterial metabolism. Nature, Lond. 174, 353. 
Winder, F. \& Denneny, J. M. (1955). Utilization of metaphosphate for phosphorylation by cell-free extracts of Mycobacterium smegmatis. Nature, Lond. 175, 636.

Winder, F. G. \& Denneny, J. M. (1956). Phosphorus metabolism of mycobacteria: determination of phosphorus compounds in some mycobacteria. J. gen. Microbiol. 15, 1.

Yoshida, A. \& Yamataka, A. (1953). On the metaphosphate of yeast. I. J. Biochem. (Japan), 40, 85.

(Received 15 April 1957) 